\title{
PENGEMBANGAN METODE IMPROVISASI KETOPRAK UNTUK PELATIHAN TEATER MODERN JUDUL TONIL
}

\author{
Nanang Arizona \\ Institut Seni Indonesia Yogyakarta, Indonesia
}

\begin{abstract}
Abstrak: Tujuan umum penelitian ini adalah mengembangkan metode improvisasi dalam ketoprak menjadi metode pelatihan dalam teater modern, sehingga menghasilkan metode pelatihan yang sistematis, aplikatif, dan terukur. Tujuan khusus penelitian ini adalah: (1) mengidentifikasi metode improvisasi dalam ketoprak sebagai upaya penggalian nilai-nilai tradisi; (2) merancang metode improvisasi untuk pelatihan teater modern; (3) mengaplikasikan metode improvisasi dalam pelatihan teater modern. Penelitian ini dirancang dengan pendekatan reseach and development. Penelitian ditindaklanjuti dengan pengembangan metode dan aplikasi metode dalam pelatihan dan pementasan. Langkah-langkah penelitian adalah: (1) pengumpulan data; (2) pengelolaan data ; (3) analisis data; (4) merancang metode; (4) implementasi metode; (5) penyempurnaan metode. Penelitian ini bersifat multi years yang dirancang dalam dua tahap. Tahap pertama adalah mengidentifikasi metode improvisasi ketoprak, merancang metode, aplikasi metode dalam pelatihan. Tahap kedua adalah mengaplikasikan metode dalam pementasan dan penyempurnaan metode. Capaian penelitian tahap kedua ini adalah metode improvisasi untuk pelatihan teater modern dalam bentuk buku.
\end{abstract}

Kata kunci: Improvisasi, ketoprak, pelatihan teater modern

\begin{abstract}
The general objective of this research is to develop methods of improvisation in ketoprak to become training methods in modern theaters, so as to produce training methods that are systematic, applicable, and measurable. The specific objectives of this research are: (1) to identify improvised methods in ketoprak as an effort to explore traditional values; (2) designing improvised methods for modern theater training; (3) applying the improvisation method in modern theater training. This research was designed with a reseach and development approach. The research was followed up with the development of methods and application of methods in training and staging. The research steps are: (1) data collection; (2) data management; (3) data analysis; (4) designing methods; (4) method implementation; (5) perfecting the method. This research is a multi-year study designed in two stages. The first stage is to identify ketoprak improvisation methods, design methods, application methods in training. The second step is to apply the method in staging and perfecting the method. This second stage of research is an improvised method for training modern theater in book form.
\end{abstract}

Key words: Improvisation, ketoprak, modern theater training

\section{Pendahuluan}

Seni pertunjukan yang tumbuh dan berkembang di Jawa, yaitu ketoprak memiliki teknik bermain yang unik yang disebut improvisasi. Tradisi bermain dengan cara improvisasi ini menjadi salah satu ciri teater rakyat, termasuk ketoprak. Jakob Sumarjo (1992) menyebut salah satu ciri teater rakyat adalah penyajian dengan improvisasi dialog, tarian, dan nyanyian. 
Bermain dengan teknik improvisasi hakikatnya bermain secara spontan tanpa berdasarkan naskah tertulis.

Sejak awal kemunculannya, ketoprak menggunakan teknik improvisasi. Ketoprak lesung yang sederhana itu menggunakan teknik improvisasi dalam bermain. Dalam berimprovisasi, pemain berpedoman pada cerita yang sederhana dan mengembangkan menjadi sebuah pertunjukan. Akan tetapi, cerita yang sederhana dapat menjadi pertunjukan yang menarik karena kepandaian para pemain dalam berimprovisasi. Cerita yang sama akan melahirkan pertunjukan yang berbeda tergantung kemmpuan para pemain dalam berimprovisasi.

Kesuksesan ketoprak komersial seperti Siswo Budoyo tak lepas dari kemampuan improvisasi para pemain. Ketoprak komersial yang setiap malam harus bermain memang tidak memungkinkan untuk menghafalkan naskah sebagaimana dalam teater modern. Hal ini menunjukkan bahwa improvisasi memiliki peran penting dalam pembentukan seorang aktor sekaligus membuka peluang dijadikan sebagai sebuah metode dalam pelatihan teater. Metode improvisasi belum dikembangkan menjadi metode latihan yang komprehensif.

Improvisasi menjadi metode bermain ketoprak yang sampai saat ini masih dipraktikkan. Improvisasi menjadi kekuatan sekaligus memberikan keunikan permainan pada pertunjukan ketoprak. Bermain secara improvisatoris berarti para pemain tidak perlu menghafalkan naskah sebagaimana dalam pertunjukan teater modern. Persiapan pertunjukan relatif lebih pendek dibanding kalau seorang aktor harus menghafalkan naskah.

Metode improvisasi sebenarnya sangat menarik dan memiliki potensi untuk dikembangkan. Rendra (1993) menyebut improvisisi sebagai ciptaan spontan saat itu juga. Dalam pertunjukan ketoprak para aktor tidak pernah memegang naskah tertulis. Permainan didasarkan pada alur cerita yang telah dibuat. Para pemain berdialog, bergerak, berpindah, berlaku secara spontan tanpa perencanaan terlebih dahulu.

Metode improvisasi juga dapat dikembangkan untuk memecahkan persoalan pembelajaran teater di sekolah. Dalam mata pelajaran Seni Teater di SMP dan SMA, proses pembelajaran sering terkendala oleh alokasi waktu dalam setiap semester. Selain itu improvisasi memiliki banyak manfaat bagi seorang calon pemain. Selain memberi solusi dalam proses membuat pertunjukan teater, improvisasi juga dapat mengembangkan kemampuan aktor secara lebih maksimal. Melalui improvisasi, pemain dikondisikan untuk tangkas dan cekatan dalam menanggapi peristiwa. Dialog yang harus diucapkan secara spontan membuat pemain berpikir cepat dan terstruktur.

Pemain dilatih membangun cara berpikir dan bertindak yang logis dalam setiap improvisasi. Dengan demikian improvisasi sebagai sebuah metode yang diparktikkan oleh teater-tetaer rakyat, dalam hal ini ketoprak, layak dikembangkan sebagai sebuah metode yang terstruktur untuk pelatihan dalam teater modern. Selain itu, improvisasi juga membentuk karakter pemain menjadi seorang yang percaya diri, tangkas, dan memiliki logika berpikir kuat. Improvisasi sebagaimana dipaparkan Rendra (1993) tidak hanya sekedar tindakan spontan, tetapi juga melatih daya cipta aktor. Pernyataan Rendra ini menegaskan bahwa improvisasi sebagai suatu metode latihan mampu meningkatkan daya cipta, daya kreasi, kepercayaan diri seorang aktor.

\section{Metode Penelitian}

Metode pada hakikatnya adalah penyelidikan berlangsung menurut suatu rencana tertentu (Peursen, 1985). Paparan 
Peursen ini mengindikasikan bahwa suatu penelitian harus menggunakan metode agar hasil yang dicapai sesuai dengan tujuan. Oleh karena itu dibutuhkan sebuah desain penelitian yang tersusun dengan baik dan terukur.

Penelitian ini dirancang dengan menggunakan pendekatan Research and Development (R\&D), yaitu penelitian yang ditindaklanjuti dengan pengembangan dan desiminasi suatu model melalui proses aksi, refleksi, evaluasi, replica, dan inovasi yang dilakukan secara sistematis dan terkait (Bogdan dan Biklen, 1982). Penelitian ini dipaparkan dalam beberapa langkah: 1) observasi sebagai cara untuk mengumpulkan data; 2) wawancara mendalam, 3) pengorganisasian hasil pengumpulan data; 4) analisis data; 5) penyusunan metode. 6) program aksi yaitu implementasi metode yang telah dirancang.

Penelitian ini mengacu pada sumber primer berupa pertunjukan ketoprak yang menggunakan teknik improvisasi. Sumber primer akan diamati secara langsung dalam sebuah pergelaran sekaligus direkam untuk dapat mengamati dan menganalisis lebih cermat. Sumber sekunder juga dibutuhkan untuk menunjang data primer. Sumber sekunder berupa literatur atau dokumen yang berkaitan. Narasumber yang terdiri dari aktor-aktor ketoprak diharapkan mampu memberikan informasi tentang teknik improvisasi yang dilakukan.

\section{Hasil dan Pembahasan}

Improvisasi merupakan teknik permaian, yaitu bergerak dan berdialog secara spontan. Teknik ini menjadi teknik utama dalam menggelar pertunjukan ketoprak. Para pemain tidak menghafalkan naskah sebagaimana dalam teater modern. Dalam teater modern, pemain harus menghafal naskah yang membutuhkan waktu yang relatif panjang. Berbeda dengan ketoprak yang tidak membutuhkan proses latihan yang panjang untuk menyiapkan sebuah pertunjukan.

Selain itu improvisasi merupakan teknik yang dapat mengembangkan kemampuan seorang pemain. Rasa percaya diri, ketangkasan, kesigapan, kepekaan, dan kecerdasan seorang pemain dalam memerankan tokoh dapat dicapai dengan cara berlatih improvisasi. Hal ini dibuktikan oleh para maestro ketoprak yang mampu membawakan berbagai macam tokoh secara utuh dengan metode improvisasi.

Metode improvisasi perlu dielaborasi untuk dikembangkan menjadi metode yang lebih terstruktur dan terukur. Bagaimana improvisasi dilakukan dan persiapan apa yang harus ditempuh untuk berimprovisasi belum pernah dituliskan dalam bentuk metode yang komprehensif. Satu hal yang dapat dipastikan bahwa improvisasi tidak sekedar tindakan spontan. Untuk melakukan improvisasi pasti dibutuhkan berbagai perangkat. Perangkat untuk berimprovisasi dengan baik belum teridentifikasi.

Pada kenyataannya teater modern masih membutuhkan metode yang komprehensif sebagai metode alternatif. Berkaitan dengan hal ini, maka perlu adanya penyusunan metode improvisasi yang bertolak dari teknik improvisasi teater tradisional, dalam hal ini ketoprak. Improvisasi dalam permainan ketoprak merupakan kekayaan metode pelatihan yang perlu dikembangkan.

Perkembangan berikutnya menunjukkan bahwa ketoprak menjadi seni pertunjukan yang lebih kompleks. Ketoprak tidak hanya memainkan peristiwa sehari-hari yang sederhana, tetapi memainkan lakonlakon babad, sejarah, Cerita Panji, dan lakon-lakon lain dari luar Jawa. Musik iringan yang dulu hanya lesung, rebana, dan seruling akhirnya menggunakan gamelan lengkap slendro dan pelog. Satu hal yang tetap menjadi ciri dalam teknik bermain ketoprak, yaitu menggunakan teknik 
improvisasi. Permainan ketoprak dalam dialog, akting, dan bloking masih tetap pada prinsip improvisasi. Begitu pula lagu-lagu sebagai pengiringnya (Sudyarsana, 1989).

Teater modern tidak menggunakan teknik improvisasi dalam bermain, walaupun sulit terbantahkan bahwa improvisasi sebagai suatu metode permainan memiliki potensi untuk dikembangkan. Improvisasi sangat baik untuk melatih daya cipta aktor (Rendra, 1993). Artinya bahwa improvisasi menjadi metode yang tidak sekedar tindakan spontan, tetapi memiliki dimensi lain, yaitu mengembangkan kemampuan seorang aktor.

Rendra (1993) membagi improvisasi menjadi empat, yaitu improvisasi solo, improvisasi dengan perabot, improvisasi berpasangan, dan improvisasi dalam kerangka cerita. Keempat pola improvisasi yang dipaparkan Rendra dapat ditemukan dalam improvisasi ketoprak. Improvisasi solo dapat ditemukan ketika pemain ketoprak ngudarasa, yaitu monolog pendek yang berisi curahan hati atau pikiran. Improvisasi dengan perabot dapat ditemukan pada adegan-adegan peperangan ketika para pemain memainkan senjata dan property yang terdapat dalam pertunjukan. Improvisasi berpasangan dapat ditemukan ketika terjadi antawacana atau dialog. Sedangkan improvisasi dengan jalan cerita jelas menjadi motode permainan pokok dalam ketoprak. Ketoprak tidak menggunakan naskah lengkap yang berisi dialog.

Improvisasi ketoprak lebih kaya lagi dengan adanya improvisasi melantunkan tembang yang dilakukan para pemain. Tembang atau nyanyian Jawa menjadi ciri yang terdapat dalam ketoprak. Selain itu, adagen dagelan yang membuat penonton tertawa paling tepat jika menggunakan metode improvisasi. Bagi para pemain ketoprak, kreativitas justru akan muncul ketika adanya peluang bagi para pemain untuk melakukan improvisasi (Susanto, 2000).

Metode improvisasi ketoprak akan dikembangkan untuk dapat mengakomodir dua pendekatan akting dalam teater modern, yaitu representasi dan presentasi. Akting representasi pada dasarnya berusaha untuk mengimitasikan dan mengilustrasikan tingkah laku karakter (Sitorus, 2003). Akting representasi berusaha menciptakan bentuk karakter yang dapat dilihat di atas panggung. Sedangkan pendekatan presentasi mengutamakan identifikasi antara jiwa si aktor dengan jiwa si karakter (Sitorus, 2003). Metode improvisasi dapat dikembangkan untuk dua pendekatan akting yang terdapat dalam teater modern, yaitu presentasi dan representasi.

Improvisasi dalam Ketoprak

Pementasan ketoprak memiliki teknik pemanggungan yang menarik, yaitu improvisasi. Improvisasi mengandalkan pada kekuatan para pemain dalam menampilkan karakter tokoh tanpa tergantung pada naskah. Pada mulanya, ketoprak sama sekali tidak menggunakan naskah. Segala sesuatu dilakukan secara spontan atau improvisasi, mulai dari dialog, gerak, sampai perpindahan pemain. Improvisasi dapat mewujudkan pertunjukan yang baik jika didukung oleh kemampuan pemain. Spontanitas dan improvisasi dalam ketoprak memang sulit - terutama bagi pemula (Mintardja, 1997).

Ketoprak dalam pemanggungannya tidak menggunakan naskah utuh sebagaimana dalam teater modern. Pada awalnya naskah ketoprak merupakan catatan-catatan saja yang ditulis dalang di papan tulis yang digantungkan di dalam ruang pemain (Mintardja, 1997). Para pemain akan membaca urutan lakon yang ditulis oleh dalang di papan tulis tersebut. Catatan yang dibuat dalang meliputi urutan adegan, nama pemeran di dalam cerita, dan 
persoalan pokok yang harus diucapkan pemain. Berdasarkan catatan itulah, para pemain memainkan perannya di atas panggung.

Dalang yang dimaksud dalam sebuah pementasan ketoprak identik dengan sutradara dalam teater modern. Dalang dalam pementasan ketoprak biasanya adalah pimpinan grup ketoprak atau pemain yang memiliki kemampuan dan pengalaman yang lebih dibanding dengan yang lain. Dalam beberapa grup ketoprak, dalang atau sutradara melakukan pengarahan kepada pemain. Pengarahan dilakukan untuk menjelaskan cerita lebih detail dan memberikan arahan terkait dengan pemanggungan. Pengarahan yang dilakukan oleh dalang atau sutradara ini dalam ketoprak disebut penuangan.

Pengarahan yang dilakukan sutradara memberikan manfaat yang besar bagi keberhasilan sebuah pertunjukan. Para pemain akan mendapatkan cerita sekaligus tafsir sutradara, sehingga aspek dramatik pertunjukan dapat terwujud. Demikian juga karakter tokoh lebih utuh dan konflik terwujud dengan baik. Selain itu para pemain mendapatkan pedoman garis-garis pengadegan yang dilakukan. Cerita menjadi lebih padu dan tidak melebar ke hal-hal lain yang tidak penting. Kecenderungan yang sering terjadi dalam improvisasi adalah cerita yang melebar pada hal-hal yang tidak penting dan merusak struktur dramatik sebuah cerita.

Catatan cerita yang diberikan kepada pemain hanya berupa garis besar yang biasa disebut wos. Garis besar cerita menjadi pedoman utama bagi seorang pemain dalam menjalankan sebuah lakon. Berikut adalah contoh naskah ketoprak yang hanya berisi catatan-catatan pengadegan atau wos.

Berdasarkan naskah tersebut pemain melakukan improvisasi. Pedoman yang dipakai pemain dalam improvisasi adalah permasalahan yang harus diungkapkan dan suasana yang dituliskan serba terbatas. Dengan demikian tugas seorang pemain ketoprak adalah melakukan improvisasi dialog, gerak, dan perpindahan dalam permainan. Seorang pemain membutuhkan keterampilan, wawasan, dan kecakapan dalam mengungkapkan dialog sekaligus membawakan karakter tokoh sebagaimana dimaksud dalam cerita.

Aspek-aspek Dramatik Improvisasi dalam Ketoprak

Seorang pemeran atau aktor ketoprak dituntut mampu membawakan karakter tokoh dengan baik. Keberhasilan seorang pemeran ketoprak ditentukan oleh pengalaman, keterampilan, dan pengetahuan yang dimiliki. Pengalaman terkait dengan jam terbang. Seorang pemain yang memiliki pengalaman memerankan tokoh Raja Brawijaya beberapa kali tentu lebih baik dibanding dengan pemeran yang baru memainkan tokoh sekali. Keterampilan berdialog, berakting, dan menghayati karakter tokoh juga akan menambah keberhasilannya dalam berperan. Pengetahuan seorang pemeran juga menentukannya dalam melakukan improvisasi saat berperan. Seorang pemeran Raja Brawijaya yang tidak mengetahui sejarah hidup Raja Brawijaya juga tidak akan mampu berimprovisasi dan bermain dengan baik.

Keberhasilan seorang pemeran ketoprak pada umumnya ditentukan dari kemampuannya dalam teknik bermain. Kemampuan teknik bermain seorang aktor ketoprak meliputi wiraga, wirama, wicara, wirasa, duga prayoga, dan greget saut. Dalam berimprovisasi aspek-aspek tersebut harus diwujudkan oleh seorang pemeran ketoprak. Aspek-aspek tersebut terkait satu sama lain menjadi satu kesatuan yang padu.

Wiraga terkait dengan penguasaan tubuh pemeran. Wiraga pada prinsipnya menyangkut kemampuan gerak dalam 
mewujudkan karakter tokoh. Dalam teknik berperan teater modern, wiraga menyangkut fleksibelitas tubuh pemeran. Artinya, dalam ketoprak pun tuntutan seorang pemeran tidak sebatas tampilan fisik akan tetapi, gerak yang mampu mengungkapkan karakter. Dengan demikian dibutuhkan latihan yang intensif.

Aspek berikutnya adalah wicara. Wicara dalam teater modern identik dengan berbicara. Wicara adalah kemampuan mengolah dialog dengan baik. Dalam ketoprak dialog biasa disebut antawacana. Berbeda dalam teater modern di mana dialog telah ditulis secara utuh dalam naskah. Improvisasi dalam ketoprak memungkinkan seorang pemeran kehilangan kesanggupan berdialog, karena tidak tertulis.

Wirama merupakan aspek lain yang penting dalam bermain ketoprak. Dalam melakukan improvisasi seorang pemeran tidak hanya dituntut kemampuan bergerak dan berdialog, tetapi gerak dan dialog tersebut harus memiliki wirama atau irama agar tidak membosankan. Irama terkait dengan variasi cepat dan lambat dalam berdialog maupun bergerak. Wirama ini terkait langsung dengan duga prayoga. Duga Prayoga itu identik dengan timing dalam teknik berperan teater modern. Selain itu juga berhubungan dengan greget saut, yaitu ketangkasan dan ketepatan dalam mengungkapkan dialog antar tokoh. Greget saut ini akan menghasilkan irama yang bagus jika sesuai dengan konflik yang terjadi. Saut artinya melontarkan dan menanggapi dialog dengan timing yang tepat.

Aspek terakhir yang penting dalam berimprovisasi adalah mengungkapkan wirasa. Wirasa terkait dengan penghayatan terhadap tokoh yang dimainkan. Wirasa menyangkut permasalahan rasa, yaitu bagaimana seorang pemeran ketoprak mampu membawakan seluruh kandungan kejiwaan tokoh. Dalam teater modern penghayatan ini bisa didapat melalui olah rasa. Berbeda dengan ketoprak, olah rasa dilakukan berdasarkan jam terbang, sensibilitas, dan wawasan yang dimiliki oleh seorang pemeran. Pada saat improvisasi dibutuhkan konsenterasi dan penghayatan terhadap tokoh yang dimainkan sehingga improvisasi yang dilakukan mampu memberikan ekspresi yang utuh. Dialog, gerak, dan irama harus didukung oleh penghayatan dalam memerankan tokoh.

Tahap-tahap Improvisasi

Improvisasi dalam permainan ketoprak memiliki beberapa tahap. Tahap pertama adalah memahami naskah, yaitu memahami catatan-catatan yang dibuat oleh dalang atau sutradara. Tahap berikutnya adalah pengarahan, yaitu dalang atau sutradara memaparkan alur cerita, karakter tokoh, dan capaian artistik secara detail. Hal ini dilakukan agar tidak menyimpang dari garis laku yang sudah ditetapkan.

1. Membaca Catatan Pengadegan

Naskah dalam ketoprak berupa catatan pengadegan yang dibuat oleh sutradara. Pemeran tergantung dari catatan yang dibuat sutradara sebagaimana telah dipapaparkan pada paparan terdahulu. Pemeran mencermati lakon yang dimainkan, tokoh yang diperankan, urutan peristiwa, serta catatan-catatan yang dibuat oleh sutradara. Catatan yang dibuat sutradara biasanya hanya catatan-catatan singkat yang menjelaskan konflik yang berlangsung. Berdasarkan catatan yang serba sedikit itu pemeran mendapat bekal untuk berimprovisasi dalam bermain. Capaian dalam improvisasi tergantung pada kemampuan pemain. Pemain yang memiliki wawasan luas dan kaya pengalaman akan mampu berimprovisasi dengan baik. Sebaliknya, pemeran yang serba miskin wawasan dan pengalaman akan menemui berbagai kesulitan dalam berimprovisasi.

2. Pengarahan Dalang atau Sutradara 
Dalam perkembangan ketoprak, pengarahan dibutuhkan agar gagasan sutradara dapat diwujudkan oleh pemeran. Pengarahan yang dilakukan dalang atau sutradara juga membantu pemeran dalam berimprovisasi. Pemeran mendapat garisgaris laku yang harus dipatuhi. Hal ini untuk mencapai aspek dramatik dan menghindari penyimpangan laku berperan dan potensi berkembang ke arah yang tidak dikehendaki. Pada saat ini grup ketoprak menyediakan waktu khusus untuk pengarahan, yaitu waktu latihan yang singkat. Berbeda dengan masa lalu, di mana sutradara melakukan pengarahan beberapa menit sebelum pertunjukan berlangsung. Penyediaan waktu khusus dilakukan agar para pemeran mendapat gambaran yang lebih utuh tentang pemanggungan. Hal ini dilakukan, terutama, jika para pemeran adalah generasi muda yang masih membutuhkan pengalaman dalam berimprovisasi. Generasi muda yang bermain ketoprak sebagian besar belum memahami aspek dimensi tokoh dan pemanggungan.

3. Improvisasi Permainan

Berbekal pemahaman tentang lakon, tokoh, dan aspek pemanggungan, pemeran melakukan improvisasi. Improvisasi permainan bagi para pemeran pemula membutuhkan kosentrasi yang tinggi. Bagi pemeran yang sudah berpengalaman, improvisasi tidak menjadi masalah. Beberapa aktor ketoprak senior, setelah pengarahan dilakukan, ia bisa bersantai dengan berbincang dengan pemeran yang lain. Bahkan tokoh-tokoh yang munculnya pada adegan akhir-akhir, biasa ditinggal di warung kopi. Aktor senior macam ini sudah tahu betul kapan akan tampil di atas pentas. Ketika gilirannya bermain, ia sudah tahu betul perkembangan dramatik dan takaran emosi yang harus dimainkan. Berbeda dengan generasi pemudu yang belum tinggi jam terbang yang dimiliki, mereka akan mengikuti peristiwa demi peristiwa dalam pementasan.

Teknik-teknik Improvisasi

Improvisasi membutuhkan teknik dan orientasi agar mampu peristiwa yang akan disampaikan bisa terwujud. Orientasi merupakan semacam jalan yang mengantarkan seorang pemeran mengungkapkan dialog, gerak, dan perpindahan dalam berimprovisasi. Sebagaimana dipaparkan Spolin (2011),

Orientation is not to be looked upon as a mere introductory or "getting acquainted" process. Indeed, players who do not receive proper Orientation are generally much slower to grasp subsequent acting problems.

Secara garis besar bahwa orientasi tidak hanya dipandang sebagai proses pengantar atau "berkenalan" saja. Akan terlihat bahwa pemain yang tidak menerima orientasi yang tepat, pada umumnya akan jauh lebih lambat untuk memahami permasalahan dalam akting selanjutnya.

Dalam melakukan improvisasi seorang pemain akan dapat berakting dengan baik jika diawali dengan pemahaman terhadap persolan yang hendak diutarakan. Pemaham akan didapat jika seorang pemain memperoleh orientasi yang komprehensip pada awal pementasan. Orientasi dalam ketoprak dapat dilihat pada pengarahan yang dilakukan oleh sutradara. Tahap orientasi adalah tahap di mana dalang atau sutradara memberikan suatu gambaran tentang pemanggungan yang akan dihadirkan. Dengan demikian pemain mendapatkan semacam pintu untuk masuk pada peristiwa yang harus dihadirkan di atas panggung.

Orientasi sebagai bekal awal yang harus dimiliki seorang pemain dalam melakukan improvisasi. Selain orientasi, Spolin (2011) memberikan lima hal penting yang dapat dijadikan pegangan dalam berimprovisasi, yaitu fokus (focus), 
deskripsi dan contoh (description and example), pengarahan (side-coaching), evaluasi (evaluation), dan poin observasi (points observation). Lima hal pokok ini menjadi kunci keberhasilan dalam melakukan improvisasi.

Teknik-teknik improvisasi dalam paparan berikut merupakan beberapa contoh pengolahan dari teknik-teknik improvisasi dalam ketoprak. Teknik tersebut diolah dari observasi terhadap proses dan pemanggungan ketoprak dan wawancara dengan tokoh-tokoh ketoprak di Yogyakarta. Penyusunan teknik tersebut diawali dengan dua paparan penting dari Spolin, yaitu orientasi, fokus, deskripsi dan contoh, pengarahan, evaluasi, dan poin observasi. Artinya setiap aktivitas dalam melatih teknik improvisasi pas diawali dengan orientasi dan lima aspek kunci yang dipaparkan Spolin. Teknik-teknik yang dipaparkan masih berupa rancangan yang perlu diuji coba dalam praktik latihan sebelum ditetapkan sebagai sebuah metode pelatihan.

1. Improvisasi Wicara

Dialog dalam ketoprak disebut antawacana. Antawacana menjadi bagian dari wicara atau pengucapan. Berdasarkan hasil pengamatan dan wawancara, wicara dapat berupa monolog (ngudarasa) dan dialog (antawacana). Ngudarasa dalam permainan ketoprak sering dilakukan oleh pemeran ketika mengungkapkan harapan, kegundahan, atau guyonan (lawakan) para pemeran yang memainkan tokoh-tokoh yang komikal. Teknik dalam melakukan improvisasi wicara akan dibagi menjadi dua, yaitu monolog dan dialog.

\subsection{Monolog (Ngudarasa)}

Monolog atau ngudarasa dilakukan oleh para pemeran ketoprak sebagai cara dalam mengungkapkan persoalan dalam lakon. Selain itu, ngudarasa dalam ketoprak juga mengungkapkan aspekaspek psikologis tokoh. Berikut adalah beberapa contoh teknik-teknik improvisasi dalam bentuk monolog yang telah disusun.

a. Kata Berkait

Kata berkait merupakan teknik improvisasi yang bertujuan mengembangkan rasa percaya diri dalam mengucapkan rangkaian kata yang bermakna. Seorang pemeran pada umumnya memiliki rasa kurang percaya diri dalam mengucapkan kata-kata sesuai dengan karakter tokoh yang dimainkan. Kata-kata yang sesuai terkait dengan pilihan kata-kata (diksi) dengan kandungan makna sebuah dialog.

Kata berkait ini membutuhkan lima atau enam pemain. Mulanya seorang pemain mengucapkan satu kata. Pemain berikutnya mengulang dan menambah satu kata. Kata-kata yang terangkai harus logis dan bermakna. Jika seorang pemain gagal, maka diulang dari awal.

b. Udar Rasa

Udar Rasa merupakan satu bentuk latihan improvisasi dengan mengekspresikan emosi yang diungkapkan dalam bentuk monolog. Pelatih memberikan instruksi berupa satu bentuk emosi, misalnya marah, senang, sedih, dan sebagainya. Peserta latihan mengekspresikan emosi tersebut dalam bentuk monolog. Isi monolog lebih pada ungkapan perasaan. Latihan ini menekankan pada aspek kemampuan mengungkapkan emosi. Pelatih bisa menginstruksikan berbagai bentuk emosi secara bergantian. Peserta latihan akan memainkan emosiemosi tersebut.

\subsection{Dialog (antawacana)}

Dialog dalam ketoprak disebut antawacana, yaitu percakapan dua orang 
atau lebih. Alur cerita dalam pementasan dapat diketahui melalui dialog yang diungkapkan oleh pemain. Dialog menjadi media utama dalam mengungkapkan sebuah lakon. Improvisasi dialog dilakukan antar tokoh berdasarkan konflik dan peristiwa yang berlangsung.

\subsection{Improvisasi Gerak}

Improvisasi gerak merupakan suatu bentuk improvisasi yang mengekspresikan emosi atau peristiwa melalui gerak. Sederhananya adalah gerak spontan di atas panggung. Gerak tersebut mengekspresikan karakter tokoh sekaligus peristiwa. Gerak bisa disertai dengan dialog, tetapi ada juga gerak tanpa dialog. Gerak yang disertai dialog biasanya bersifat menegaskan, memperkuat, atau berupa kode-kode tertentu yang berhubungan dengan dialog. Sementara, gerak tanpa dialog adalah gerak yang mengungkapkan ekspresi tertetu tanpa terkait dengan dialog. Gerak tanpa dialog ini bisa berupa isyarat, gerak ilustrasi, atau gerak-gerak yang bersifat stilistik. Gerak-gerak stilistik bisa berupa tari atau gerakan-gerakan silat yang dilakukan di atas panggung.

\section{Improvisasi Wirasa}

Improvisasi wirasa merupakan improvisasi yang menekankan pada ekspresi emosi. Improvisasi ini terkait dengan inner action seorang pemain, yaitu kemampuan menghayati emosi tokoh dan mengekspresikannya. Dialog dan gerak di atas panggung tidak akan bermakna jika tidak disertai dengan takaran

\section{Simpulan}

Ketoprak dengan teknik bermain secara improvisasi merupakan teknik yang dipelajari melalui pengalaman ketika pementasan berlangsung. Seseorang yang ingin menjadi pemain handal, satu-satunya cara adalah nyantrik atau magang. Melalui nyantrik seseorang akan memperoleh pengalaman secara langsung dengan cara mengamati pemain senior dan praktik bermain dalam sebuah pementasan. Pemain pemula akan merasakan pengalaman bermain dengan memerankan tokoh-tokoh pembantu yang tidak memiliki porsi permainan yang banyak. Biasa terjadi seorang pemula hanya berdiri sebagai pengawal dan tidak melakukan akting yang lain. Hal semacam itu sudah sangat berharga bagi seorang pemula. Baru ketika jam terbang bermainnya dipandang cukup, maka porsinya ditambah.

Nyantrik membutuhkan waktu yang relatif panjang untuk bisa bermain atau berimprovisasi dengan baik. Dalam proses semacam itu tidak terjadi transfer pengetahuan dan keterampilan secara langsung. Pola semacam inilah yang menjadi salah satu faktor teknik-teknik improvisasi yang dimiliki oleh seniman ketoprak sulit didokumentasikan dengan baik. Seniman ketoprak yang sudah senior pun kadang tidak menyadari sepenuhnya tentang teknik-teknik yang ia kuasai. Pada tataran inilah penelitian membutuhkan strategi agar semua hal tentang improvisasi dapat digali dan disusun menjadi sebuah metode.

Cara yang dapat ditempuh adalah menggali pengalaman bermain dan menggali hal-hal yang terkait dengan improvisasi dengan wawancara secara lebih mendalam. Cara itu juga dapat diperkuat dengan melakukan pengamatan secara lebih intensif, baik pada saat persiapan pementasan, pementasan, bahkan dalam kehidupan sehari-hari. Teman sejawat dan keluarga dekat terkadang dapat memberikan informasi yang berharga.

Kesimpulan lain yang penting adalah ditemukannya beberapa cara improvisasi dan persiapan-persiapan yang dilakukan. 
Seorang pemain ketoprak senior dapat melakukan improvisasi dengan baik ketika telah memiliki pengalaman, wawasan, penguasaan psikologis, serta pengetahuan tentang tokoh yang akan dimainkan. Pengalaman yang dimaksudkan adalah jam terbang dalam bermain ketoprak. Wawasan yang dimaksudkan adalah pengetahuan tentang hal-hal yang terkait dengan tokoh yang dimainkan. Penguasaan psikologis adalah ketenangan, kesanggupan mengendalikan suasana, dan ketangkasan dalam menghadapi berbagai perubahan yang terjadi dalam permainan.

Improvisasi ketoprak yang dapat diturunkan menjadi metode pelatihan teater modern meliputi improvisasi monolog, improvisasi dialog, improvisasi gerak, dan improvisasi pengadegan. Masing-masing bentuk improvisasi memiliki teknik-teknik yang dapat dikembangkan dalam model-model latihan. Seseorang dapat berimprovisasi dengan baik jika menguasai alur cerita, menguasai karakteristik tokoh, menguasai tulang punggung pengadegan, dan menguasai aspek-aspek dramatik dalam setiap adegan.

\section{Daftar Pustaka}

Bogdan, R. S. \& Biklen. (1982). Qualitative Research for Education: An Introduction to Theory and Methods. Boston: Allyn and Bacon.

Rendra. (1993). Seni Drama untuk Remaja. Jakarta: Pustaka Jaya.

Sitorus, E.D. (2003). The Art of Acting Seni Peran untuk Teater, Film dan TV. Jakarta: Gramedia Pustaka Utama.

Spolin, V. (2011). Improvisation for The Theater A Handbook of Teaching and Directing Techniques, Northwestern: Northwestern University Press.

Sudyarsana, H. K. (1989). Ketoprak. Yogyakarta: Kanisius.
Susanto, B. S. J. (Ed.). (2000). Imajinasi Penguasa dan Identitas Postkolonial Siasat Politik (Kethoprak) Massa Rakyat. Yogyakarta: Kanisius.

Van Peursen, C.A. (1985). Susunan Ilmu Pengetahuan. Jakarta: Gramedia Pustaka Utama. 